\title{
ВУКОВА ЋИРИЛИЦА У ЦЕЛОСНОЈ СЛИЦИ РАЗВОЈА СЛОВЕНСКИХ СИСТЕМА
}

У току историје словенски језици употребљавају три алфабета: глагољски, ћирилски и латинички. ${ }^{1}$ На самом почетку словенске писмене културе, у тесној вези с византијском ћирило-методском моравском мисијом, стоји глагољица, прави „проналазак” Константина-Филозофа (Ћирила); он је намерно саставио ново писмо у којем су само реминисценције на азбуке које је познавао (нпр. ехо грчког, латинског и хебрејског писма). И у данашњем је погледу Константинова глагољица веома савршено писмо. Само се палатални сонанти /l', r', ń/ у старим рукописима изражавају помоћу дијакритичког лучића; фонолошка самосталност вокала $\ddot{u}$ и $\ddot{o}$ (у налазу $\ddot{o} N$ ) је сумњива; тројно $i$ и дуго $\sigma$ сигурно су били алофонски гласови; постоји графема за грчко ипсилон, за $f$ и ваљда и за палатално $x^{\prime}\left(=c h^{\prime}\right) .^{2}$ Помоћу диграфа изражава се фонема /y/ $=<\mathrm{b}+\mathrm{i}>$ (што можда има фонетску подлогу); знак за $/ \mathrm{u} /=0+$ „ижица” је више лигатура него диграф. (Прозодијска обележја вокала само изузетно налазе израз у писму.)

${ }^{1}$ Има, као што је познато, и изузетака: постоје словенски текстови написани грчким, хебрејским и арапским писмом; то су специјални и маргинални случајеви мотивисани посебном културном средином.

2 Усп.: F. V. Mareš, Hlaholice and Moravě a v Čachách, Слово, 21, 1971, 133-200 (тамо се наводи и литература предмета); N. S. Trubetzkoy, Altkirchenslavische Grammatik. Schrift-, Laut- und Formensystem, hrsg. R. Jagoditsch, 2, Aufl., GrazWien-Köln, 1968; J. Vajs, Rukovět hlaholské paleografie, Praha, 1932; V. Tkadlčik, Systém hlaholské abecedy, Studia paleoslovenica (= sbornik J. Kurze), Praha, 1971, 357-377; F. V. Mareš, Die Anfänge des slavischen Schrifttums und die kulturelle Selbständigkeit der Slaven, Wiener Slavistisches Jahrbuch, 16, 1970, 77-88; Ф. В. Мареш, Историскиот развој на македонскиот в окален систем, Македонски јазик, 34, 1983, 5-21; Ф. В. Мареш, Фонолошки иновации во македонскиот јазик и во неговите дијалекти, Прилози - МАНУ (у штампи). 
Друга половина X века и XI век су периоди темељних промена у словенском фонолошком систему; ту почиње и његова дубља територијална диференцијација. То смањује фонемско-графемску равнотежу глагољице. Три знака за $i$ постају потпуно хомофонички; слово „шта” добија вредност št (и често се употребљава недоследно, паралелно с $\mathcal{u}+m$ ), код Хрвата има вредност $\dot{c}$, š́ ; „ђерв” се резервише за грчко меко гамма (већ од IX века?). Сонант $ј$ појачава своју позицију у систему и ради тога се почиње разликовати $e N$ и jeN. У корист фонемско-графемске равнотеже дефинитивно се губи „паукасто” $x(c h)$ и према локалним условима лагано ишчезава z $(d z)$.

Од XII века глагољица се активно чува само код Хрвата и њена фонемско-графемска пропорција током времена и језичког развоја даље се смањује; пре свега нека слова постају редундантна (нпр. јерови, назали, диграф „јери” итд.). То доводи око половине XIII века до битне и добре реформе глагољице у хрватском Приморју и на острвима. ${ }^{3}$ У резултату се углавном реституише равнотежа „фонема-графема”; сувишне графеме или су биле укинуте или су се сачувале само у бројној вредности.

Поред глагољице, код југоисточних Словена веома рано се конституише ћирилица - најпре, вероватно, у профаној употреби, али сигурно већ у X веку и у литургији; од почетка XII века искључиво преузима све функције глагољице у сфери византијског обреда. Првобитна је ћирилица заснивана на моделу глагољице, из ње преузима и већину графема за словенске гласове непознате грчком језику. Углавном се већ у X веку развио графијски систем који одражава промене у фонолошкој структури језика, односно редакцијских варијаната. Назали нису више имали дифтоншки карактер, дакле уместо глагољских слова $e N, o N,(\ddot{o} N)$ употребљавају се монографи ґ, х. Старо „широко” /ä/ дефинитивно се распада у /ě/ и $j a$ ('a); сонант $j$ што даље тим чвршће се укорењује у саставу

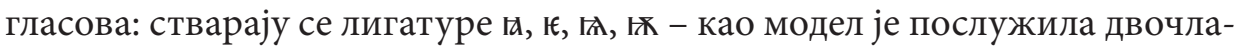
на интерпретација знака ю (који је у ствари преобликован из глагољског монографа за /ü/. По грчком се узору /u/ пише помоћу диграфа $о y$, али и грчко в рано улази у ћирилску графију; двојним се диграфом и даље пише $/ y /$ : 'ы или ъи (доцније: ы). Палатални сонанти /l', $r$ ', $n$ / најчешће се

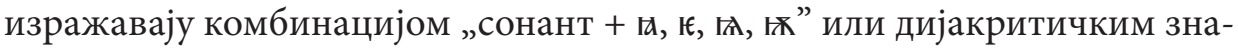

${ }^{3}$ F. V. Mareš, A basic reform of the orthography at the early period of Croatian-glagolitic Church Slavonic, The Formation of the Slavonic Literary Lanugages, ed. by G. Stone and D. Worth, Columbus (Ohio), 1983, 177-181. 
ком изнад следећег „нејотованог” вокала; ${ }^{4}$ само на руском подручју понекад се употребљавају посебни графеми за $l$ ' и $n$. У једном делу руских рукописа долази и $ч$ са дијакритичким знаком које означава $\breve{3}$ у групи žž $(\check{z} d \check{z})$, што је уосталом с фонолошке тачке гледишта редундантно. Слово щ служи сагласно територијалним редакцијама и етимолошком пореклу

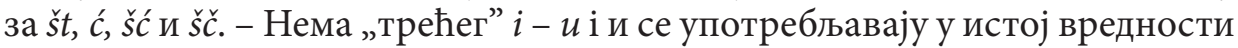
- или promiscue, или с тенденцијом вештачке норме (постоје и рукописи c једним $i$ ); слично важи за $o$ и $\omega$. У туђим речима долази не само $\oint$ и ижица, него и друга грчка слова: ncu, фита/muта у бројној вредности (у XI в.) и коппа.

Најстарију историју ћирилице можемо окарактерисати с једне стране као одраз преобраћаја гласовног репертоара у фонетском (нпр. монографемски знаци за назале), делимично и у фонолошком погледу $(/ j /)$; присутно је и зближавање с грчким графијским системом.

Белешка. Историја ћирилице добро је представљена у специјалним радовима посебно Е. Ф. Карскога, В. Н. Шчепкина, П. Ђорђића 5 . Недавно се појавила подробна монографија Ј. Кристофсона која исцрпно разматра ћирилску азбуку и правопис у целом току историје. ${ }^{6}$ Ту се можемо (и морамо) ограничити на неопходну кратку карактеристику.

У току столећа битно се променио фонолошки систем: нема више јерова, позната је различита дубина назала, јата, гласа „јери”, изгубила се дистинктивна функција палаталних вокала, на североисточном се словенском подручју фонологизује корелација немеких и меких консонаната и сонаната. Графијски израз мења своју стару вредност. Јерови се пишу углавном по традицији; има неколико нових дублета $(o y / y-\mathbf{x}$, А-ґ, ы - U...), разуме се у тесној вези с локалном језичком средином или под утицајем других подручја („второе южнославянское влияние” у Русији). Стварају се и нове варијанте слова („дубоко” $e$, „широко” о и $\omega$ ). Појављују се реформе којима је циљ да се уведе ред у хаотичну ситуа-

4 Усп. Нпр.: V. Mošin, I più antichi manoscritti cirilliani, Tre alfabeti per gli Slavi, Bibl. Apost. Vaticana, 1985, 37-53.

${ }^{5}$ Е. Ф. Карский, Славянская кирилловская палеография, Ленинград, 1928; В. Н. Щепкин, Русская палеография, 2-ое изд., Москва, 1967; П. Ђорђић, Историја српске ћирилище, Београд, 1971.

${ }^{6}$ J. Kristophson, Klassifikation von Orthographiesystemen, Ein Beitrag zum Varhältnis von Sprache und Schrift. Dargestellt am Beispiel slavischer kyrillischer Orthographien, München („Hieronymus”), 1986. 
цију (уређени рашки правопис, Јефимије Трновски, Константин Костенецки). За разлику од споменуте реформе хрватских глагољаша, која се вероватно оријентисала на средњовековни латински правопис у Италији (или и на талијански правопис), реформе ћирилице на подручју византијске културе су се оријентисале на узор грчког правописа. Као што је познато, грчки је алфабет обиловао хомофоничним графемама, нпр. епсилон - алфа + иота; иота - ета - епсилон + иота - (доцније и:) ипсилон - омикрон + иота, ипсилон + иота итд.; правопис се ограничавао на правила за употребу слова и наредних знакова. Такве су тенденције постојале и у развитку словенског ћирилског писма и ортографије. Граматике Мелетија Смотрицког (1619) и А. Мразовића (1794) дан-данас служе као правописна норма новоцрквенословенског језика. Иако је Мелетијев правопис доста сложен, треба признати да има једну велику предност: помоћу разних графема и надредних знакова битно олакшава гласно читање ex abrupto. На први поглед разликују се хомофонични облици једнине и множине, придевски облик на -о и прилог, значења неколико лексичких хомонима, лако се уочава граница речи (што је важно у рукописима), тачно је означен нагласак итд. То је све посебно корисно за литургијску праксу.

Темељита је била у Русији реформа Петра Великог (на почетку XVIII века), али и она је сачувала два дублета ( $u-i, e-, j a m ”)$, туђа слова фuта и ижица, као и јер на крају речи; тек је совјетска реформа укинула и тај недостатак (само слова фита и ижица већ раније су изашла из употребе). Ипак, у североисточним словенским језицима (рус., укр., белорус.) тешко се може остварити принцип „фонема = графема”: фонолошки релевантна корелација немеких и меких консонаната и сонаната јако компликује ситуацију. Осим тога, историјска функција руског правописа не дозвљава превелике принципијелне промене.

За латиницу само укратко: после доста хаотичних примитивних и

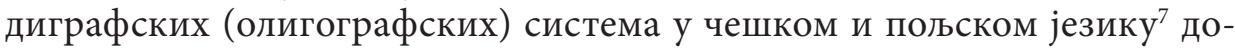
шао је Јан Хус са својом генијалном реформом (поч. XV в.). Помоћу дијакритичких знакова (цртица - „акут” и тачка - доцније квака) успео је да оствари латинички систем по принципу „фонема = графема”; само за $/ \mathrm{x} /$ је оставио диграф $c h$ и сачувао је графему $x$ у вредности $k+s .{ }^{8}$ Графијски систем хрватске глагољице (коју је упознао у прашком Емаузу)

7 Слично је било доцније код других словена који се служе латиницом.

8 Усп.: J. Schröpfer, Hussens Traktat „Orthographia Bohemica”, die Herkunft des diakritischen Systems in der Schreibung slavischer Sprachen und die älteste zusammenhängende Beschreibung slavischer Laute, Wiesbaden, 1968. 
дао је Хусу идеју за његову правописну реформу. ${ }^{9}$ И релевантне дужине чешких самогласника имају адекватан израз у писму. - Хусов су систем доцније углавном преузели други словенски језици с латиничком абецедом (Гај!) са изузетком пољског; у том је погледу корелација (кон)сонаната по мекоћи један од главних разлога због којих се у пољском језику не може лако апликовати доследна дијакритичка ортографија (иако је такав предлог разрадио већ у XV веку Јан Паркошовиц). ${ }^{10} \mathrm{Ta}-$ кође, пољска традиција не допушта ни сада такав експеримент. - Треба још забележити да се у данашњим правописима поновно употребљавају неки диграфи ( $l j, n j, d z ̌$, у луж.-срп. језицима корелација по мекоћи обележава се помоћу -j-).

Добро је позната новија историја српске ћирилице и њеног правописа. Руско-новоцрквенословенска ${ }^{11}$ граматика Мелетија Смотрицког је била прештампана 1755. год., граматика Мразовића је изашла 1794. (сп. горе). - Славеносрпски језик није остварио никакву сопствену доследну норму писма и правописа. Независно од ових струја један сразмерно висок фонемско-графемски стандард је постигла доцнија босанчица (босанска ћирилица), ${ }^{12}$ барем у неким писарским школама.

После неколико покушаја реформе (најпознатији је предлог Саве Мркаља - 1810) долази Вук. Он успешно врши темељиту реформу која представља прелом у историји. Увео је графему ј и укинуо сва „јотована” слова за секвенце „/j/ + самогласник”. Укинуо је хомофоничне дублете, дебело и танко јер (дебело јер неко време му је служило као помоћна ознака за гласовно $r$ у суседству вокала), слово „шта” и туђе графеме $\kappa c u$, nси, фита/тита, ижица. Од старог је „ђерва” обликовао $\hbar$ и $ђ$, увео је нове графеме ть и юь. (Неке графеме имају и код Вука своју историју, посебно $\varnothing, x$ и ,јат”.) На тај је начин Вук успео саздати једну од најсавршенијих азбука Европе и света. ${ }^{13}$ Додуше, ни Вуков систем не респектује у потпуности фонолошку структуру језика: не бележи релевантне вредно-

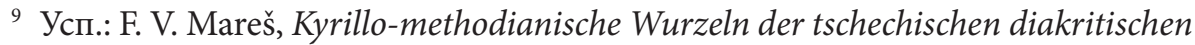
Orthographie, Anzeiger der phil.-hist. Klasse der Österreichischen Akademie der Wissenschaften, 110, 1973, 81-99.

10 Усп.: S. Urbañczyk (unter Mitarb. R. Olesch), Die altpolnischen Orthographien des 16. Jahrhunderts, Köln-Wien, 1983.

${ }_{11}$ За периодизацију старословенског и цел. језика види: F. V. Mareš, An Anthology of Church Slavonic Texts of Western (Czech) Origin, München, 1979, 11-13.

12 Усп.: Ђорђић, нав.дело, 169-170.

13 За историју и оцену Вукове реформе и делимично и предвуковског раздобља види: Љ. Стојановић, Вук Стеф. Карачић, юегов рад на српском језику и правопису, Београд, 1899; Вук Стеф. Караџић, Српски рјечник 1818, ур. П. Ивић, 
сти прозодијског плана - квантитет и интонацију. ${ }^{14}$ Као што је познато, за лингвистичку се сврху Вук служио дијакритичким прозодијским знаковима Луке Милованова (овај је систем усавршио Ђ. Даничић у другом издању Вуковог Рјечника), но из паметних и исправних разлога није их увео у општу употребу (усп. Ивић, нав.дело; у српско-хрватском је језику сасвим другачија ситуација него у чешком и словачком, који дијакритичком цртицом означавају дуге вокале).

Након више од 120 година кодификатори македонског књижевног језика (са Б. Конеским на челу) адаптирали су Вукову ћирилицу за македонски језик. Из старе су ћирилице поново преузели слово $s$ („дзјело”) за фонему $/ z / .{ }^{15}$ Место сх. $\hbar$ и $ђ$ увели су ќ и ź са дијакритичком цртицом. За туђу и дијалекатску фонему /э/ примили су знак апострофа који нема место у азбучном реду и служи истовремено као сигнал слоговног $r$, ако се тај фон не налази између двају (кон)сонаната (нпр. 'pж, за'рза). С фонолошке тачке гледишта Вукови знаци $\hbar$ и $ђ$ могли би служити и као адекватне графеме за македонске фонеме /ќ/ и /ѓ/ (као што нпр. лат. графема $j$ у неким језицима означава /j/, у другим /ž/ или /̌̌/ или /x =ch/). На тај би се начин избегла употреба дијакритичке цртице која не одговара структури Вукове ћирилице. Међутим, идентификација самосталног књижевног језика тражи баш овакав израз ортоепске ситуације и у графијској (оптичкој) слици језика. - И македонска кћи Вукове ћирилице представља један од фонолошки најсавршенијих графијских система.

Белешка. Русински језик употребљава украјински вид азбуке. ${ }^{16}$ С обзиром на фонолошки систем он би се могао без потешкоћа служити Вуковом ћирилицом и постићи фонетско-графемску равнотежу. Графеме $s$ і $u$ адекватно би замениле диграфе $\partial з$ и $ә ж$ (који имају високу фреквенцију, посебно $\partial 3)$, применом графема $j, \preccurlyeq$, юь и $\hbar, \hbar$ (односно $m^{\prime}, \partial^{\prime}$ ) адекватно би се елиминисала четири знака „јотованих" вокала $(я, \epsilon, \ddot{i}, ю)$, као и графеме $\breve{u}$ и $b$; монографемски знак

Београд, 1966 - поговор: П. Ивић, О Вуковом Рјечнику из 1818. године, додаци, 19-188 (V, Азбука и правопис, 64-70, VI. Акценти, 71-78).

${ }^{14}$ Нагласак (акцент) нема дистинктивну вредност; усп. Ф. В. Мареш, српско-хрватски новоштокавски прозодијски систем (у синхроничном погледу), Зборник радова посвећен Р. Бошковићу, Титоград, 1988, 223-229.

15 О фонемској вредности гласа 3 в. Ф. В.М., фонолошки иновации... (в. фусн. 2), 75-76 (3.2.3.1). - У македонском азбучном реду слово $<$ s $>$ стоји између /ж/ и $<$ и $>$, иако је његово старо место у ћирилици било између /ж/ и /3/ (са бројном вредношћу грчке дигамме, тј. =6).

16 Усп.: М. М. Кочиш, Правопис рускога язика, 3. вид., Нови Сад, 1980. 
за секвенцу $/ \check{s} /+/ \check{c} /$, тј. $\mathfrak{u}_{2}$, могао би се заменити спојем $\mathfrak{u}+\mathcal{u}$ (као у белоруском језику; усп. и сх. и мак. $и$ и $m$ : училиште), евентуално би се могао сачувати као карактеристично обележје русинске азбуке (поред $m$ ', d’?). У сваком случају, потребне су три посебне графеме за $/ \mathrm{x}-\mathrm{h}-\mathrm{g} /$, то јест $x-2-i$. Но објективно треба истаћи да је данашњи русински правопис израз културног идентитета на који свака заједница има свето право.

Азбука у којој се свака фонема датог језика изражава једном адекватном графемом представља у лингвистичком погледу савршен систем. Обично се још више цени ако се тај циљ постигне без употребе дијакритичких знакова. Међутим, такав „идеал” једва да је остварљив у потпуној мери. Тако је и у историји словенског писма - увек остају ситне маргиналне недоследности - у глагољици, у Хусовом правопису, у Вуковој ћирилици (прозодијски план). Писмом се служе не само лингвисти, састав писме не сме се преоптеретити теретском доследношћу, иако би она била, у чисто научном смислу, логична и оправдана. - И као што је писани језик природно трајнији него жив говор, тако су и писмо и правопис по својој нарави конзервативнији него жива реч и не могу одржати корак с развитком језика (што је уосталом добро позната чињеница). Ако на тај начин несразмеран развој језика и писма води до хаотичног стања у правопису, с правом можемо говорити о декаденцији. Излаз из такве ситуације се остварује двојаким путем. Једна је могућност да се правопис регулише на основу историје језика и добрих писарских традиција. Такав, више или мање историјски правопис, органски се надовезујући на духовно благо прошлости, не прекида везу с књижевном баштином и остварује важан израз дубоких културних вредности - макар понекад по цену смањене једноставности (нпр. данашњски руски правопис). Друга је могућност темељита, принципијелна реформа писма, повратак ка најприроднијем систему по правилу „фонема = графема”. ${ }^{17}$ Такав посту-

17 На избог првог или другог пута може евентуално утицати и један угледан модел: различите реформе старе ћирилице следе у неком смислу грчку графију и ортографију; реформаторима хрватске глагољице у XIII веку био је познат развој латинског правописа у Италији, одн. и почеци талијанског правописа; Хус се инспирисао емауском глагољицом (в. фусн. 9); Вуку је био познат Хусов правопис. 
пак у ствари уопште није повратак, него нов почетак. У 1100-годишњој историји словенског писма такав је догађај увек сигнал нове и велике епохе. За успешно остварење таквог „препорода” азбуке увек је потребно не само зрело време, него и снажна, генијална личност. У току више него једног миленија словенске писмености има у том смислу четири доминанте: ${ }^{18} 1$. Настанак глагољице уочи 863 . године, то јест на почетку словенске писмене културе, када се Словени „прибројише великим народима" (ЖК XIV); преславни је аутор глагољице сам св. Константин Солунски (Ћирил). - 2. Генијална реформа угласте глагољице коју су извршили анонимни хрватски глагољаши око половине XIII века, кад су постигли официјално папинско одобрење за словенско богослужење према западном обреду. - 3. Успешни дијакритички (латинички) правопис Јана Хуса на почетку XV века, кад се у XIV веку завршио процес формације и богатог развитка чешког књижевног језика и чешке литературе. - 4. На прагу препорода словенских народа, на почетку нове славне културне епохе јужних Словена стоји аутор перфектне српскохрватске ћирилице - Вук Стефановић Караџић.

* Рад је претходно објављен у зборнику Научни састанак слависта у Вукове дане, 17/1, 43-48

18 Сличне услове имају и важне - да се послужим музичким термином „субдоминанте”, нпр. настанак првобитне ћирилице (св. Климент Охридски?), развитак босанчице, гражданка Петра Великог, Гајева адаптација Хусовог правописа и сл. (Не мислим да би ту била корисна дискусија где је граница између условних појмова „доминанта” и „субдоминанта”). 